\title{
The effect of government spending on macroeconomic stability
}

\author{
Keyvan Karimi ${ }^{a^{*}}$, Rahebe Ghasemzade ${ }^{\text {b }}$ Payam Khodaei ${ }^{a}$ and Payam Abdi ${ }^{\mathrm{c}}$
}

${ }^{a}$ Department of Accounting, Shahindezh Branch, Islamic Azad University, Shahindezh, Iran

${ }^{b}$ Department of Computer Science, Shahindezh Branch, Islamic Azad University, Shahindezh, Iran

${ }^{c}$ Department of Management, Shahindezh Branch, Islamic Azad University, Shahindezh, Iran

\section{H R O N I C L E}

Article history:

Received June 5, 2015

Received in revised format

August 162015

Accepted December 212015

Available online

December 222015

Keywords:

Macro-economy stability

The Johansen-Juselius method

Government spending

\section{A B S T R A C T}

\begin{abstract}
Macroeconomic stability plays essential role on the performance of governments and attaining economic development. Therefore, governments can displace the demand curve and achieve different goals such as economic development and growth by considering financial instruments, which are available for them. Thus, the present study aims at investigating the effect of government spending on the stability of macro-economy for the time interval 19792011 using the Johansen-Juselius method. The results indicate that the variables of goods price index and services as well as government investment spending had positive effects and variables of exchange free rate, government consumption spending, and government tax revenues had negative effects on economic development.
\end{abstract}

C 2016 Growing Science Ltd. All rights reserved.

\section{Introduction}

The necessity and significance of macroeconomic stability has been the focus of several economists after the presentation of a report by the World Bank in 1991. Macroeconomic stability has important signs on the orientation of macroeconomic policies, monetary and financial credit of a country for economic agents. Particularly, the success of all programs of amending the economic structure such as financial reformations, modification policies, making free and purposive energy subsides require the existence of macroeconomic stability. Consequently, there is a significant correlation between economic development and macroeconomic stability of a country. Accordingly, in the present study, after the introduction section, the theoretical framework is investigated. Then, the proposed methodology of this paper is explained and data analysis is discussed. Finally, conclusion is presented to summarize the contribution of the paper.






\section{Theoretical framework and review of literature}

The necessity and significance of macroeconomic stability has been at the focus of economists' attention after the presentation of a report given by the World Bank in 1991. In this report which investigated the performance of countries in 70's and 80's, it was indicated that countries with economic stability had better coordination in governments' policies than instable countries (World Bank, 1991). After the attention of the World Bank to the significance of economic stability, some economists have investigated the effects of government policies on economic development (Levine \& Renelt, 1991, 1992; Ghura \& Hadjimichael, 1996; Orden \& Fisher, 1993). According to Gorji and Madani (2003), macroeconomic stability increases national saving and private investment and, by reinforcing competitions in export, improves balance of payments. In addition, macroeconomic stability pursues important signs regarding the orientation of macroeconomic policies and monetary and financial credit in a country for economic agents. Particularly, the success of all programs of amending the economic structure such as financial reformations, modification policies, making free and purposive energy subsides requires the existence of macroeconomic stability (Khalili Araghi \& Ramzanpour, 2002). Consequently, there is a significant correlation between economic development and macroeconomic stability of a country in such a way that macroeconomic stability results in the trust of economic activists in future upheavals and consequently draws a clear vision of the future. Therefore, macroeconomic stability can contribute significantly to the real economic development. In addition, macroeconomic stability as one of the factors in economic development, particularly was considered (Frenkel \& Khan, 1990; Easterly \& Rebleu, 1993).

Studies conducted by International Monetary Fund indicate that economic instability is the main factor of stagnation in most of countries. Therefore, it is expected that the adoption of plans for making macroeconomics stable and structural reformations can be effective on the access to high economic development (Norouzi, 2001). In addition, regarding the fact that one of the important economic sectors in each country is the government which, in addition to providing security based on the viewpoint of the minimum government intervention, can play significant role on economic management and production. Accordingly, it can have negative and positive effects on the production of the private sector and, at last, the total economic production (Doessel \& Valadkhani, 2003). Doing the mentioned activity and playing roles imposed by the government necessitate spending and since one of the measurement criteria of the government is not available in the literature, government spending is associated with the growth domestic products (GDP); therefore, the significant intervention of governments in economy implies that the appropriate role and size of governments are challenging arguments among economists and statesmen (Gholami, 2009).

Regarding the investigation of government size on the economic development in empirical literature, there are some findings, which are contradictory and the positive effect of government size on economic development is indicated (Ram, 1986; Kormendi \& McGuire, 1985; NORAD, 2000), while Lando (1994), Cameron (2002) and Khalili Araghi and Ramzanpour (2002) believe that government spending has negative effects on economic development.

Accordingly, a general law and principle for the relationship between government size and economic development in different countries cannot be presented and the findings in one country cannot be generalized to another one. The relationship between government spending and economic development is not clear in economic theories. However, it is expected that by creating required infrastructure and providing services appropriately and efficiently, governments contribute to economic development (Komeijani \& Nazari, 2009). Therefore, governments can displace the demand curve using financial instrument available for them and accordingly, they can obtain important objectives such as production development or the reduction in employment, curbing inflation, and economic stability. In this line, financial policies refers to a set of measures of governments regarding government spending, taxes and transfer payments, which can be applied to attain the mentioned objectives. Therefore, financial policies as active elements of macroeconomics, construct a revolution initiated by Keynes in economics. Before 
him, classists believed basically in the necessity of government intervention in economy. The main issue in Keynes' ideas is associated with the expansion of governments' activities in government productive, economic, and investment affairs for attaining complete employment level. In this line, the direct effect of each kind of financial policy will be transition curve. Some Iranian researchers investigated the effects of government spending on economic development using the Autoregressive Distributed Lag (ARDL) models. Their results indicated that the increase in government' construction expenditures had direct and significant effects on economic development, but government' consumption expenditure had no significant effect on economic development. Rahbar and Sargolzaei (2011), in a study investigated the effect of government spending on economic development from 1984 to 2007 using the ARDL and VAR models. The results indicated that the increase in government's consumption spending in short-term period results in the decrease in economic development rate. Komeijani and Nazari (2009), using the Auto-regression Model, investigated the effect of government size on the economic development in Iran. They concluded that the effect of government spending on economic development was positive and compatible with the Keynes' economic theory. Kandil (2001) investigated the effects of the contractionary and expansionary shock shocks of financial policies on economic development for USA during 4/1998 to 1/1987 using the Hodrick-Prescott (HP) filter. The results of the present study indicated that the contraction and expansion shocks of financial policies in a government was a sustainable process predicted during the time period. Berument and Dogan (2004) in their study investigated the asymmetrical effect of government spending shocks on the production of Turkey for the time period from 1/1987 to 1/2000 using the Hodrick-Prescott (HP) filter. The results indicated that private consumption and investment reduce in spite of government expansionary shock, while the occurrence of contractionary shocks, no reduction in private consumption and investment. Tagkalakis (2008) investigated the asymmetrical effect of financial policies on the private consumption during business cycles of boom and bust for 19 countries of OECD) from 1970-2002 using the panel data method. The results indicated that the effect of financial policies on the private consumption in the periods of recession more than period of prosperity.

\section{Methodology}

In the present study, using the theoretical framework and empirical studies, i.e. the ARDL and VDCF models in the time period from 1959 to 2003, the survey investigates the effects of financial policies on economic development using the following regression function,

$G D P R=F(C P I R, E R R, G C R, G D P R, G I R, T T R)$,

where GDPR, TTR, GCR, GIR, CPIR and ERR represent gross domestic product, tax revenues growth, government consumption expenditure growth, the growth of government investment expenditure, goods and services consumer price index growth, market exchange rate growth, respectively.

In addition, in the present study, to estimate the model, the Johansen-Juselius convergence method using the Eviews 7 software has been employed. In this method, first the reliability of the variables of the model was investigated and then, the optimization of the VAR model was determined by the SBC test. The reason for using the Johansen-Juselius convergence method instead of other convergence methods is that this method has been considered more than a convergence vector among the model variables and in case of using this method, estimators will have asymptotic efficiency. Accordingly, to estimate the long-term relations among variables, the Johansen-Juselius convergence method has been used. Johansen-Juselius, by formulizing a method for the vector cointegration, could remove the deficiencies of the Engle-Granger two-step method. In addition, to investigate the reliability of variables, the Augmented Dickey-Fuller test (Table 1) or the Phillips-Perron test has been used (Gujarati, 2012). In the next stage, it is necessary that the existence or absence of the number of convergence vectors be investigated using the matrix effect test and the maximum eigenvalues. To do so, two statistics of the maximum of eigenvalues (Table 3,4) and the effect test were used (Tashkini, 2009). The selected optimal vector has been investigated. Finally, to analyze data and estimate the model, the vector auto-regression (VAR) (Table 2) has been employed. 
Table 1

The results of the Augmented Dickey-Fuller test and Phillips-Perron test

\begin{tabular}{|c|c|c|c|c|c|c|}
\hline \multirow[t]{2}{*}{ Variable name } & \multicolumn{3}{|c|}{ The ADF test } & \multicolumn{3}{|c|}{ The PP test } \\
\hline & $\begin{array}{l}\text { At level and intercept } \\
\text { and temporal trend }\end{array}$ & $\begin{array}{c}\text { One-stage } \\
\text { differencing and } \\
\text { with intercept }\end{array}$ & $\begin{array}{c}\text { Two-stage } \\
\text { differencing and } \\
\text { with intercept }\end{array}$ & $\begin{array}{l}\text { At level and intercept } \\
\text { and temporal trend }\end{array}$ & $\begin{array}{c}\text { One-stage } \\
\text { differencing and } \\
\text { with intercept }\end{array}$ & $\begin{array}{c}\text { Two-stage } \\
\text { differencing and } \\
\text { with intercept }\end{array}$ \\
\hline $\operatorname{lnCPI}$ & -2.05 & -3.90 & - & -1.68 & -3.84 & - \\
\hline $\begin{array}{c}\text { MacKinnon critical values at } \\
\text { Sig. } 5 \%\end{array}$ & -3.55 & -2.95 & - & -3.55 & -2.95 & - \\
\hline LnERR & -2.75 & -2.86 & -6.12 & -2.38 & -2.78 & -6.63 \\
\hline $\begin{array}{c}\text { MacKinnon critical values at } \\
\text { Sig. } 5 \%\end{array}$ & -3.55 & -2.95 & -2.96 & -3.55 & -2.95 & -2.95 \\
\hline LnGCR & -2.33 & -5.04 & - & -2.48 & -5.11 & - \\
\hline $\begin{array}{c}\text { MacKinnon critical values at } \\
\text { Sig. } 5 \%\end{array}$ & -3.56 & -2.95 & - & -3.54 & -2.95 & - \\
\hline $\operatorname{lnGIR}$ & -2.53 & -2.01 & -8.76 & -2.29 & -4.90 & - \\
\hline $\begin{array}{c}\text { MacKinnon critical values at } \\
\text { Sig. } 5 \%\end{array}$ & -3.56 & -2.96 & -2.96 & -3.54 & -2.95 & - \\
\hline $\operatorname{lnGDP}$ & -2.47 & -4.22 & - & -2.09 & -4.25 & - \\
\hline $\begin{array}{c}\text { MacKinnon critical values at } \\
\text { Sig. } 5 \%\end{array}$ & -3.56 & -3.95 & - & -3.55 & -2.95 & - \\
\hline $\operatorname{lnTTR}$ & -2.04 & -5.02 & - & -2.80 & -5.02 & - \\
\hline $\begin{array}{c}\text { MacKinnon critical values at } \\
\text { Sig. } 5 \%\end{array}$ & -3.55 & -2.95 & - & -3.55 & -2.95 & - \\
\hline
\end{tabular}

\section{Table 2}

The number of optimal lags in the VAR model

\begin{tabular}{lccccc}
\hline Schwartz-Bayesian test values & (SBC) & -10.68 & $-18.22 *$ & -16.13 & -17.42 \\
\hline Number of lags & 0 & 1 & 2 & 3 \\
\hline
\end{tabular}

\section{Table 3}

Matrix effects test

\begin{tabular}{ccccc}
\hline Null hypothesis & Opposite hypothesis & Test values & Critical value at 95\% & Probability value at level 95\% \\
\hline $\mathrm{r}=0^{*}$ & $\mathrm{r}=1$ & 227.04 & 103.84 & 0.0000 \\
$\mathrm{r}=1^{*}$ & $\mathrm{r}=2$ & 119.71 & 76.97 & 0.0000 \\
$\mathrm{r}=2^{*}$ & $\mathrm{r}=3$ & 75.50 & 54.07 & 0.0003 \\
$\mathrm{r}=3^{*}$ & $\mathrm{r}=4$ & 41.37 & 35.19 & 0.0095 \\
$\mathrm{r}=4^{*}$ & $\mathrm{r}=5$ & 24.23 & 20.26 & 0.01354 \\
\hline
\end{tabular}

\section{Table 4}

The results of maximum eigenvalues

\begin{tabular}{ccccc}
\hline Null hypothesis & Opposite hypothesis & Test values & Critical value at 95\% & Probability value at level $95 \%$ \\
\hline $\mathrm{r}=0^{*}$ & $\mathrm{r}=1$ & 107.32 & 40.95 & 0.0000 \\
$\mathrm{r}=1^{*}$ & $\mathrm{r}=2$ & 44.21 & 34.80 & 0.0029 \\
$\mathrm{r}=2^{*}$ & $\mathrm{r}=3$ & 34.13 & 28.58 & 0.0088 \\
$\mathrm{r}=3$ & $\mathrm{r}=4$ & 17.14 & 22.29 & 0.2247 \\
$\mathrm{r}=4^{*}$ & $\mathrm{r}=5$ & 16.34 & 15.89 & 0.0424 \\
\hline
\end{tabular}

\section{Table 5}

Estimating convergence vectors

\begin{tabular}{cccc}
\hline Variable test & Coefficient & SD & T student test values \\
\hline logGDP* & 1 & 0 & 0 \\
logCPI & 1.28 & 0.20 & 6.4 \\
$\operatorname{logERR}$ & -0.66 & 0.05 & -13.2 \\
$\operatorname{logGCR}$ & -0.15 & 0.40 & 0.375 \\
$\operatorname{logGIR}$ & 0.92 & 0.12 & 7.66 \\
logTTR & -1.24 & 0.08 & 15.5
\end{tabular}

* convergence vector has been normalized in relation with the variable logGDP.

***regarding the fact that the Johansen - Juselius method does not show the probability values; therefore, the significance of the coefficient explanatory variables of the values of t-student was used. 
Results of Table 5 indicate that the CPI and GIR have had positive and significant effects on economic development in such a way that per variation as one percent in the CPI, the economic development of the country will be as $1.28 \%$. Accordingly, regarding the government's investment spending, per variation as one percent in the GIR, there will be $0.92 \%$ of economic development. In addition, the ERR, GCR, and TTR have had negative effects on economic development in such a way that the ERR had $0.66 \%$ of negative effect on economic development due to one percent variation. The GCR had $0.15 \%$ percent of negative effect on economic development per one percent variation. Accordingly, per one percent variation in the TTR, the economic development faces the lack of development as 1.24 percent.

Table 6

The results of estimating the VECM model

\begin{tabular}{cccc}
\hline Variable name & Coefficient & SD & t-student value \\
\hline GDP(-1 $)$ & - & - & - \\
\hline
\end{tabular}

Table 7

Analysis variance for levels of inflation in the 10 periods

\begin{tabular}{|c|c|c|c|c|c|c|}
\hline $\begin{array}{l}\text { The TTR shock } \\
\text { share }\end{array}$ & $\begin{array}{l}\text { The GIR shock } \\
\text { share }\end{array}$ & The GCR shock share & The ERR shock share & The CPI shock share & The GDP shock share & Period \\
\hline 0 & 0 & 0 & 0 & 0 & 100 & 1 \\
\hline 1 & 5 & 4 & 9 & 0.2 & 81 & 2 \\
\hline 1 & 5 & 9 & 15 & 3 & 66 & 3 \\
\hline 0.2 & 4 & 10 & 21 & 0.8 & 64 & 4 \\
\hline 0.5 & 4 & 9 & 23 & 6 & 57 & 5 \\
\hline 0.6 & 4 & 10 & 23 & 9 & 53 & 6 \\
\hline 0.7 & 5 & 10 & 23 & 10 & 51 & 7 \\
\hline 0.8 & 5 & 10 & 23 & 11 & 50 & 8 \\
\hline 0.9 & 5 & 10 & 24 & 11 & 49 & 9 \\
\hline 1 & 5 & 10 & 24 & 12 & 48 & 10 \\
\hline
\end{tabular}

According to Table 7, the most affectedness of the GDP in the first period was from the variations of the variable itself and this trend has been reduced during the 10 year period. In addition, the CPI in the second period has been effective as 0.2 and in the third period as 3 percent on the GDP and this trend has been increased in the fourth period in such a way that in the tenth period, it has reached its peak. Accordingly, regarding the GCR, it has been effective on the GDP as 4\% in the second period, where this value has increased up to the fourth period and in the fifth period, it has increased with one unit in relation with the fourth one and continued its fixed trend up to the tenth period.

\section{Conclusion}

In the present study, the effect of the government spending on the macroeconomic stability has been investigated. Regarding the significance of macroeconomic stability and the issue that in countries enjoying economic stability, governments have had better performance than countries suffering instability; therefore, parallel to macroeconomic development and the effect of government intervention in the process of economic development increase, but regarding the theoretical framework, a general law cannot be considered for the relationship between movement size and economic development. As a result, governments, regarding their financial instruments, can displace the demand curve and obtain economic development and stability. In addition, regarding the theoretical framework and conducted studies, the most variability in the GDP was in the first period of the variable itself and this trend decreased for the next periods. Furthermore, the CPI and GIR had positive effects and the ERR, GCR and TTR had negative effects on the trend of economic development. 


\section{Acknowledgement}

The authors would like to thank the anonymous referees for constructive comments on earlier version of this paper.

\section{References}

Berument, H., \& Dogan, B. (2004). The asymmetric effects of government spending shocks: empirical evidence from Turkey. Journal of Economic and Social Research, 6(1), 33-51.

Cameron, A. D. (2002). Importance of early selective thinning in the development of long-term stand stability and improved log quality: a review.Forestry, 75(1), 25-35.

Doessel, D. P., \& Valadkhani, A. (2003). The effect of government on economic growth in Fiji. The Singapore Economic Review, 48(01), 27-38.

Easterly, W., \& Rebelo, S. (1993). Fiscal policy and economic growth.Journal of monetary economics, 32(3), 417-458.

Frenkel, J. A., \& Khan, M. S. (1990). Adjustment policies and economic development. American Journal of Agricultural Economics, 72(3), 815-820.

Gorji, E., \& Madani, Sh. (2003). Investigating the role of economic stability, economic growth performance with simultaneous equations. Journal of Commerce, 28, 24.

Gholami, E. (2009). Evaluation price shocks of oil revenues on tax revenues in Iran. Institute of Economic Affairs and Finance, a research project.

Ghura, D., \& Hadjimichael, M. T. (1996). Growth in Sub-Saharan Africa. Staff Papers-International Monetary Fund, 605-634.

Gujarati, D. N. (2012). Basic econometrics. Tata McGraw-Hill Education.

Kandil, M. (2001). Asymmetry in the effects of US government spending shocks: Evidence and implications. The Quarterly Review of Economics and Finance, 41(2), 137-165.

Khalili Araghi, M., \& Ramzanpour, E. (2002). The importance of macroeconomic stability. Economic Research Journal, 36(1).

Komeijani, A. et al. (2014). Examining the size and quality of the economic growth in Iran as co ARDL, Volume 4.

Komeijani, A., \& Nazari, R. (2009). Examining the size the state's economic growth. Economic Research Journal, 4(2).

Kormendi, R. C., \& Meguire, P. G. (1985). Macroeconomic determinants of growth: cross-country evidence. Journal of Monetary Economics, 16(2), 141-163.

Lando, D. (1994). Three essays on contingent claims pricing. Cornell University, May.

Levine, R., \& Renelt, D. (1991). Cross-country studies of growth and policy: methodological, conceptual, and statistical problems (Vol. 608). World Bank Publications.

Levine, R., \& Renelt, D. (1992). A sensitivity analysis of cross-country growth regressions. The American Economic Review, 942-963.

NORAD (1995). Guide to Planning and Evaluation NGO Projects, Number 2: Core Elements in Planning Development Assistance, Oslo: NORAD.

Norouzi, H. (2001). Effects of instability on economic growth in Iran (with the focus on inflation). MSc Thesis, Shahid Beheshti University.

Orden, D., \& Fisher, L. A. (1993). Financial deregulation and the dynamics of money, prices, and output in New Zealand and Australia. Journal of Money, Credit and Banking, 25(2), 273-292.

Rahbar, F., \& Sargolziei, M. (2011). The impact of fiscal policy on economic growth and poverty during the period 1984 to 2007. Economic Research Journal, 46(96).

Ram, R. (1986). Government size and economic growth: A new framework and some evidence from cross-section and time-series data. The American Economic Review, 76(1), 191-203.

Tagkalakis, A. (2008). The effects of fiscal policy on consumption in recessions and expansions. Journal of Public economics, 92(5), 1486-1508.

Tashkini, A. (2009). Econometrics with the help of Microfit. Tehran: Tehran Dibagaran publication. 